\title{
Retrospective Analysis of 268 Cases of Amniocentesis and Chorion Villus Sampling
}

\author{
Halil Korkut Dağlar ${ }^{1}$, Barış Kaya ${ }^{1}$, Hacı Öztürk Şahin ${ }^{1}$, Mehmet Fethi Pınar $^{1}$, Aybala Akı1 ${ }^{2}$ \\ ${ }^{1}$ Gaziantep Kadın Hastalıklarn ve Doğum Hastanesi, Kadın Doğum Kliniği, Gaziantep, Türkiye \\ ${ }^{2}$ Şehitkamil Devlet Hastanesi, Kadın Doğum Kliniği, Gaziantep, Türkiye
}

\begin{abstract}
Objective: Invasive prenatal tests have still been important and indispensable. We aimed to share the indications, results and complications of our amniocentesis and chorion villus sampling cases from Gaziantep Gynecology and Maternity Hospital.

Methods: Data from 253 amniocentesis and 15 chorion villus sampling procedures between 2010-1011 have been analyzed retrospectively.

Results: Genetic abnormality was detected in $6.8 \%$ of amniocentesis ( $n=17)$ and $26.6 \%$ of chorion villus sampling cases ( $n=4)$. $3.2 \%$ of the chromosomal abnormalities were numerical $(n=8)$ and the most common of it was trizomy $21(2.8 \%, n=7)$. Total fetal loss was $0.7 \%(n=2)$.

Conclusion: The similarity of genetic abnormality and complication rates with the literature is encouraging for the educated and experienced staff to perform invasive procedures in the hospitals except university and education hospitals.
\end{abstract}

Keywords: Amniocentesis, chorion villus sampling, karyotype, genetic analysis.

\section{Gaziantep İli Doğum Hastanesi'nde karyotip analizi amacı ile amniyosentez ve koryon villus örneklemesi yaplan 268 olgunun retrospektif analizi}

Amaç: Invazif prenatal testler, günümüzde önemini ve vazgeçilmezliğini korumaya devam etmektedir. Gaziantep ili Kadın Hastalıkları ve Doğum Hastanesi'nde gerçekleştirdiğimiz amniyosentez ve koryon villus örneklemesi işlemlerinin endikasyon dağılımlarını, sonuçlarını ve komplikasyonlarını değerlendirmeyi amaçladık.

Yöntem: 2010-2011 yılları arasında kliniğimizde karyotip analizi amacıyla genetik amniyosentez uygulanan 253 hasta ile koryon villus örneklemesi uygulanan 15 hastanın verileri, girişim endikasyonlarının dağıımı, genetik sonuçlar ve işlem esnasında karşılaşılan komplikasyonlar açısından retrospektif olarak analiz edilmiştir.

Bulgular: Serimizdeki amniyosentez yapılan olguların \%6.8'inde $(n=17)$, koryon villus örneklemesi yapılan 15 olgunun ise \%26.6'sında $(n=4)$ genetik anomali saptanmıştır. Amniyosentezde saptanan kromozom anomalilerinin \%3.2'si sayısal anomaliler $(n=8)$, bunlardan da en sık görüleni trizomi 21 idi $(\% 2.8, n=7)$. Serimizde toplam fetal kayıp oranı, \%0.7 ( $n=2)$ olarak belirlenmiştir

Sonuç: Genetik anomali ve işlem komplikasyonları oranlarının literatürde bildirilen oranlarla benzerlik göstermesi, periferde yer alan üniversite ile eğitim ve araştırma hastanesi dışındaki merkezlerde eğitimli ve deneyimli personel tarafından bu uygulamaların yapılmasının yaygınlaşması açısından cesaret vericidir. .

Anahtar Sözcükler: Amniyosentez, koryon villus örneklemesi, karyotip, genetik analiz. 


\section{Introduction}

Invasive prenatal tests are still important and indispensable despite advances in ultrasonography technology and intensive efforts to obtain fetal DNA from maternal blood. Fetal loss and rarely maternal complications may occur during these procedures. ${ }^{[1]}$ Although there isn't a non-invasive procedure of fetal karyotype determination in routine use, research is focused on this topic nowadays. This study evaluates indication procedures, results and complications of amniocentesis and chorionic villus sampling procedures applied in Gaziantep Gynecology and Maternity Hospital from 2010, when these procedures have started, to now.

\section{Methods}

Data, indications for intervention and complications during procedure of 253 patients who undergone genetic amniocentesis for karyotype analysis and 15 patients who undergone chorionic villus sampling at Gaziantep Gynecology and Maternity Hospital between 2010-2011 were analyzed. Information was given to all patients and their partners about technique of application, rate of fetal loss and other risks and complications of procedure and then informed consent was taken. All the patients were evaluated for rhesus group before the procedure and $300 \mathrm{mcg}$ anti $\mathrm{D}$ immunoglobulin was given in case of Rh incompatibility.

Mindray DP-9900 PLUS (Mindray Medical International Limited, China) ultrasound device was used for the procedure. Fetal biometry measures, fetal cardiac activity, and placenta localization were determined and recorded before the procedure.

A spinal needle of 22-Gauge was used for amniocentesis and a 20-Gauge spinal needle for chorionic villus sampling. To sterilize operation area skin irrigation with $10 \%$ povidone-iodine solution was performed twice, ultrasound probe was covered with sterile surgical glove, and all staff wore sterile gloves during the procedure. No sedation or anesthesia was used during the intervention. All the patients were checked up with ultrasound just after and one week after the procedure.
For amniocentesis $1 \mathrm{cc}$ amnion fluid sample was taken for each pregnancy week between 16th20th weeks. Amniocentesis procedure was attempted twice for patients at whom we failed to obtain enough material at first attempt and in the end we successfully got samples from all patients. During the procedure we paid attention not to involve a fetal part or cord in fluid pouch and vertical transplacental passage is used when needed to do so. Amnion fluid was aspirated with a $20 \mathrm{~mL}$ injector applying negative pressure. Chorionic villus sampling was performed between 11th-14th weeks. Approximately $10 \mathrm{mg}$ fetal tissue was obtained with a $20 \mathrm{~mL}$ injector and passed into the transfer medium. Transcervical route was never used for chorionic villus sampling. All attempts to get chorionic villus samples were successful at first trial and adequate fetal tissues were obtained from all patients. Cytogenetic material obtained from amniotic fluid were examined in Gaziantep University Medical Biology and Genetic Department using long term cell culture method, GTL and CBG banding and CVS material were examined using GTL banding method (band level 400/450). Statistical analyses of the results were made using SPSS 16.0 package program (SPSS Inc., Chicago).

\section{Results}

In our clinics amniocentesis for genetic evaluation was applied to 253 patients and chorionic villus sampling was applied to 15 patients between 2010 and 2011. Mean week $( \pm$ SD) of pregnant women when amniocentesis applied was $17.6 \pm 1.5$, their mean age was $33.29 \pm 6.57$, and $3.2 \%$ of them were smoking cigarettes. Mean week of pregnant women when chorionic villus sampling performed was $12.64 \pm 0.8$, their mean age was $32.3 \pm 6.8$, and none of them were smoking.

The most common indications were high risk in triple test $(n=212,83.8 \%$ ), and advanced maternal age (distribution of indications for amniocentesis aiming genetic assessment and chorionic villus sampling are shown in Table 1). Threshold value for high risk in triple test was accepted as 1/270. History of a childbirth with anomaly represented mothers of children with Down syndrome $(n=7$, $2.8 \%$ ), and abnormal finding in ultrasound repre- 
sented a fetus with omphalocele we detected during ultrasonography. The most common indication for chorionic villus sampling was high risk in combined test ( $n=12,80 \%)$. Threshold value for combined test was again $1 / 270$. This was due to inability of our ultrasound devices to perform Doppler of ductus venosus and to evaluate tricuspid regurgitation. We detected cystic hygroma in a patient who undergone chorionic villus sampling due to abnormal findings in ultrasound.

Amniocentesis was performed successfully to all patients, 243 (96.3\%) being at first attempt and 10 at second attempt. None of the patients required more than two attempts. Genetic results couldn't be obtained in a patient $(0.3 \%)$ due to culture failure.

Two of the 253 amniocentesis cases were twin pregnancies. One of them was referred to our center due to advanced maternal age and the other due to abnormal finding in ultrasound (bilateral choroidal cyst). Amniocentesis results of both cases were normal and they were excluded from analyses. After exclusion of twin pregnancies, genetic anomaly was detected in $6.8 \%(n=17)$ of all cases and 26.6\% ( $n=4)$ of cases who undergone chorionic villus sampling (rates of chromosomal anomalies according to indications for amniocentesis are shown in Table 2 and rates of chromosomal anomalies according to indications for chorionic villus sampling are shown in Table 3). Forty seven percent $(n=8)$ of chromosomal anomalies detected in amniocentesis were numerical and the most common was trisomy $21(87.5 \%, \mathrm{n}=7)$. All of the chromosomal anomalies in our cases are shown in Table 4.

In 2 of 253 amniocentesis procedures dark colored amniotic fluids consistent with old hemorrhages were aspirated and one of these cases ended up with fetal loss. Another fetal loss was occurred due to rupture of membranes. Total rate of fetal loss was $0.7 \%(n=2)$. Transient decrease in amniotic fluid was detected in a patient that returned to normal levels during follow up. This pregnancy reached term without chorioamnionitis. There were no fetal injuries or maternal complications.

\section{Discussion}

Amniocentesis, applied till 1800's, is the most frequent prenatal invasive test. ${ }^{[2]}$ Routine use of genetic amniocentesis was after publication of article Role of amniocentesis in intrauterine detection of

Table 1. Distribution of indications for amniocentesis aiming genetic analysis and chorionic villus sampling.

\begin{tabular}{|c|c|c|c|c|}
\hline \multirow[t]{2}{*}{ Indication } & \multicolumn{2}{|c|}{ Amniocentesis $(n=253)$} & \multicolumn{2}{|c|}{ Chorionic villus sampling $(n=15)$} \\
\hline & Patient Number & $\%$ & Patient Number & $\%$ \\
\hline High risk in triple test & 212 & 83.8 & - & - \\
\hline High risk in combined test & - & - & 12 & 80 \\
\hline Advanced maternal age & 28 & 11.1 & 2 & 13.3 \\
\hline History of a childbirth with anomaly & 7 & 2.8 & - & - \\
\hline Abnormal findings in ultrasound & 1 & 0.4 & 1 & 6.7 \\
\hline Other & 5 & 2.0 & - & - \\
\hline Total & 253 & 100.0 & 15 & 100.0 \\
\hline
\end{tabular}

Table 2. Rates of chromosomal anomalies according to the indications for amniocentesis.

\begin{tabular}{|c|c|c|c|c|c|}
\hline Indication & $N(\%)$ & Normal & Trisomy 21 & Trisomy 18 & $\begin{array}{c}\text { Structural } \\
\text { anomaly }\end{array}$ \\
\hline High risk in triple test & $212(83.8 \%)$ & $199(93.9 \%)$ & $5(2.4 \%)$ & $1(0.5 \%)$ & $7(3.3 \%)$ \\
\hline Advanced maternal age & $27(10.7 \%)$ & $25(92.6 \%)$ & - & - & $2(7.4 \%)$ \\
\hline History of a childbirth with anomaly & $7(2.8 \%)$ & $5(71.4 \%)$ & $2(28.6 \%)$ & - & - \\
\hline Other & $5(2.0 \%)$ & $5(100 \%)$ & - & - & - \\
\hline
\end{tabular}


Table 3. Rates of chromosomal anomalies according to the indications for chorionic villus sampling.

\begin{tabular}{lccccc}
\hline Indication & N (\%) & Normal & Trizomi 21 & $\begin{array}{c}\text { Turner } \\
\text { syndrome }\end{array}$ & $\begin{array}{c}\text { Structural } \\
\text { anomaly }\end{array}$ \\
\hline High risk in combined test & $12(80.0 \%)$ & $9(75 \%)$ & $2(16.7 \%)$ & - & $1(8.3 \%)$ \\
Advanced maternal age & $2(13.3 \%)$ & $2(100 \%)$ & - & - & - \\
Abnormal ultrasonography finding & $1(6.7 \%)$ & - & - & $1(100 \%)$ & - \\
\hline
\end{tabular}

genetic disorders' by Naddler et al. in $1970 .{ }^{[3]}$ At the beginning amniocentesis was performed transabdominally in a blinded fashion but after 1980's it has been performed with ultrasonography guidance. ${ }^{[4]}$ Chorionic villus sampling was first performed in Scandinavia by Mohr, transcervically in a blinded fashion. ${ }^{[5]}$ The first study of ultrasonography guided chorionic villus sampling was published by Kazy et al. in 1980. ${ }^{[6]}$ In 1990's comparisons were made between amniocentesis and chorionic villus sampling and no significant difference could be found. ${ }^{[7]}$ After study of Nicolaides et al with routine use of nuchal translucency combined with beta-hCG and PAPP-A at 11th week 13th week 6th day, chorionic villus sampling performed during this time has begun the most early prenatal invasive test. ${ }^{[8]}$

Besides widespread use of prenatal invasive tests, research about diagnostic noninvasive tests has continued due to difficulties in learning invasive methods, their risks and complications. Presence of fetal cells in maternal circulation was first detected by German pathophysiologist Gerg Schmorl when he discovered multinucleated giant cells in postmortem lungs of eclamptic pregnancies in 1893. ${ }^{[9]}$ With advances in cellular and molecular genetics, cell-free fetal DNA was discovered in $1997^{[10]}$ and fetal RNA circulating in maternal plasma was detected in 2010. ${ }^{[11]}$ In early 2000's fetal $\mathrm{Rh}$ and gender determination were performed from fetal erythrocytes obtained from maternal blood. ${ }^{[12,13]}$ In 2011, a multicenter study of 753 high risk pregnancies in England, the Netherlands and Hong Kong in which Nicolaides was also involved, multiple maternal DNA sequencing gave $98 \%$ successful results and 76 trisomy 21 fetuses were detected ${ }^{[14]}$ In the view of such information it is not difficult to predict that non-invasive tests will sophisticate very quickly and they will be com- monly used with decrease in their costs. In our country although amniocentesis, as an invasive prenatal diagnostic test, is widely used chorionic villus sampling can be performed only in certain centers. This is because results and complications of amniocentesis are understood better and it is easier to learn compared with other invasive tests. Same as Sener et al., ${ }^{[15]}$ Api et al., ${ }^{[16]}$ and Yüce et al., ${ }^{[17]}$ case series, first two indications for genetic amniocentesis were increased risk in triple test and advanced maternal age. Triple test is no more accepted as the most effective screening test for screening antenatal Down syndrome. But it is still commonly used in many countries including developed countries like England. ${ }^{[18]}$ Our clinic is a reference center for many cities in Southeast Anatolia for pregnant women who have high scores in triple test and/or who are above 35 years of age. We acknowledge that combined test couldn't become adequately widespread in this region including our city. This may be due to time consuming manner of NT measurement, and inadequacy of ultrasonography devices in some city or district hospitals to perform NT measurement. We believe that much more frequent use of amniocentesis than chorionic villus sampling is due to these factors. All of the risk analyses of chorionic villus samplings in combined test were performed in our center. We perform routine screening to all pregnant women without an age restriction as published by ACOG in 2007. ${ }^{[19]}$ But a big proportion of referred patients from peripheral cities were presented to our center directly with amniocentesis request and therefore advanced maternal age in our series included pregnant women whose age at delivery was over 35 .

In general, we detected genetic anomalies in $6.8 \%$ of amniocentesis cases and $26.6 \%$ of chorionic villus sampling cases. In literature chromoso- 
Table 4. Results of all detected chromosomal anomalies.

\begin{tabular}{|c|c|c|c|c|}
\hline Karyotype & $\begin{array}{l}\text { Maternal } \\
\text { age }\end{array}$ & Indication & $\begin{array}{l}\text { Performed interventional } \\
\text { procedure and week of } \\
\text { performance }\end{array}$ & Prognosis \\
\hline $\begin{array}{l}47, X X,+21 \text { (Regular type } \\
\text { Down syndrome) }\end{array}$ & 46 & $\operatorname{Tr} 21$ risk>1/50 & Amniocentesis- $17^{\text {th }}$ week & Terminated \\
\hline $\begin{array}{l}47, X X,+21 \text { (Regular type } \\
\text { Down syndrome) }\end{array}$ & 39 & Advanced maternal age & Amniocentesis $-17^{\text {th }}$ week & Terminated \\
\hline $\begin{array}{l}47, X X,+21 \text { (Regular type } \\
\text { Down syndrome) }\end{array}$ & 35 & $\operatorname{Tr} 21$ risk > 1/131 & Amniocentesis $-18^{\text {th }}$ week & $\begin{array}{l}\text { Patient didn't accept } \\
\text { termination }\end{array}$ \\
\hline $46,--, 1 \mathrm{qh}+$ & 37 & $\operatorname{Tr} 21$ risk >1/50 & Amniocentesis $-17^{\text {th }}$ week & Genetic counseling \\
\hline $\begin{array}{l}47, X X,+21 \text { (Regular type } \\
\text { Down syndrome) }\end{array}$ & 30 & $\operatorname{Tr} 21$ risk = 1/116 & Amniocentesis $-20^{\text {th }}$ week & $\begin{array}{l}\text { Patient didn't accept } \\
\text { termination }\end{array}$ \\
\hline $\begin{array}{l}47, X X,+21 \text { (Regular type } \\
\text { Down syndrome) }\end{array}$ & 39 & $\operatorname{Tr} 21$ risk >1/50 & Amniocentesis $-17^{\text {th }}$ week & Terminated \\
\hline $46,--, 15$ cenh+ & 47 & $\operatorname{Tr} 21$ risk = 1/39 & Amniocentesis $-16^{\text {th }}$ week & Genetic counseling \\
\hline $47, X X,+18$ & 38 & Advanced maternal age & Amniocentesis- $18^{\text {th }}$ week & Terminated \\
\hline $\begin{array}{l}\text { Heterochromatin increase } \\
46,--1 \mathrm{qh}+\end{array}$ & 41 & Advanced maternal age & Amniocentesis $-18^{\text {th }}$ week & Genetic counseling \\
\hline $\begin{array}{l}47, X X,+21 \text { (Regular type } \\
\text { Down syndrome) }\end{array}$ & 36 & $\operatorname{Tr} 21$ risk >1/50 & Amniocentesis - $17^{\text {th }}$ week & Terminated \\
\hline $\begin{array}{l}\text { Translokasyon 46,--,t (6;8) } \\
\text { (p21.2; p11.2) }\end{array}$ & 31 & $\operatorname{Tr} 21$ risk >1/50 & Amniocentesis - $16^{\text {th }}$ week & Genetic counseling \\
\hline $\begin{array}{l}\text { Translocation } \\
46,--t(5 ; 16)(q 23 ; p 12)\end{array}$ & 27 & $\operatorname{Tr} 21$ risk = 1/281 & Amniocentesis $-17^{\text {th }}$ week & Genetic counseling \\
\hline $\begin{array}{l}\text { Translocation } \\
46,--, t(7 ; 11)(q 22 ; q 14.1)\end{array}$ & 31 & $\operatorname{Tr} 21$ risk $=1 / 224$ & Amniocentesis $-17^{\text {th }}$ week & Genetic counseling \\
\hline $\begin{array}{l}\text { Pericentric inversion } \\
46, x x, \operatorname{inv}(9)(p 11 q 13)\end{array}$ & 26 & $\operatorname{Tr} 21$ risk = 1/242 & Amniocentesis $-18^{\text {th }}$ week & Genetic counseling \\
\hline $\begin{array}{l}47, X X,+21 \text { (Regular type } \\
\text { Down syndrome) }\end{array}$ & 20 & $\operatorname{Tr} 21$ risk = 1/8 & Amniocentesis - $16^{\text {th }}$ week & Terminated \\
\hline $\begin{array}{l}\text { Heterochromatin increase } \\
46,--16 \mathrm{qh}+\end{array}$ & 26 & $\operatorname{Tr} 21$ risk =1/71 & Amniocentesis $-18^{\text {th }}$ week & Genetic counseling \\
\hline $\begin{array}{l}\text { Inversion of } \\
\text { chromosome } 9\end{array}$ & 36 & Advanced maternal age & Amniocentesis $-18^{\text {th }}$ week & Genetic counseling \\
\hline $46,--, 15$ cenh+ & 41 & $\begin{array}{l}\operatorname{Tr} 21 \text { risk }>1 / 271 \text { in } \\
\text { combined test }\end{array}$ & $\begin{array}{l}\text { Chorionic villus } \\
\text { biopsy }-13^{\text {th }} \text { week }\end{array}$ & Genetic counseling \\
\hline $\begin{array}{l}47, X X,+21 \text { (Regular type } \\
\text { Down syndrome) }\end{array}$ & 20 & $\begin{array}{l}\operatorname{Tr} 21 \text { risk >1/131 in } \\
\text { combined test }\end{array}$ & $\begin{array}{l}\text { Chorionic villus } \\
\text { biopsy- } 12^{\text {th }} \text { week }\end{array}$ & Terminated \\
\hline $\begin{array}{l}47, X X,+21 \text { (Regular type } \\
\text { Down syndrome) }\end{array}$ & 27 & $\begin{array}{l}\text { Tr } 21 \text { risk }>1 / 50 \text { in } \\
\text { combined test }\end{array}$ & $\begin{array}{l}\text { Chorionic villus } \\
\text { biopsy }-13^{\text {th }} \text { week }\end{array}$ & Terminated \\
\hline $45, \times 0$ & 36 & $\begin{array}{l}\text { Abnormal } \\
\text { ultrasonography finding }\end{array}$ & $\begin{array}{l}\text { Chorionic villus } \\
\text { biopsy - 13th week }\end{array}$ & Terminated \\
\hline
\end{tabular}


mal anomaly detection rate was 3.9\% in Api et al. and $6 \%$ in Ermiş et al. studies. ${ }^{18,201}$ In our series chromosomal anomaly rate in amniocentesis was similar to these studies. In our series chromosomal anomaly rate with CVS was high but our total case number was 15 which prevents making a realistic rate comparison.

In literature rate of amniocentesis related fetal loss was reported to be between 0.2-2.1\%. ${ }^{[21-23]} \mathrm{Api}$ et al. reported $1.9 \%$, Yildırım et al. ${ }^{[22]}$ and Şener et al. ${ }^{[2]}$ reported $0.78 \%$ fetal loss rates. In our series we detected amniocentesis related fetal loss rate as $0.7 \%(n=2)$. This rate is in accordance with literature. Reason for fetal loss was amniotic fluid leakage in one of these patients. Amniotic fluid leakage is 4 times more frequent after amniocentesis. ${ }^{[2]}$ Although conservative follow up is enough for management amniopatch technique with maternal blood may be used in prolonged cases. ${ }^{[22]}$ The other fetal loss was the case we detected dark colored blood in amniocentesis consistent with old hemorrhage. Bloody fluid in amniotic fluid was reported to increase spontaneous abortion number 5 times. ${ }^{[23]}$

\section{Conclusion}

Despite all the advances, time needed for noninvasive tests to become available for routine use and continuing use of invasive tests for high risk pregnancies worldwide are proofs for continuing importance of invasive tests. We tried to prove that amniocentesis and chorionic villus sampling can be performed in a peripheric (peripheral olacak) center successfully by showing our results. Similarity of genetic anomaly and procedural complication rates with literature is encouraging to perform these procedures at peripheric (peripheral olacak) centers other than university, and research and education hospitals.

\section{References}

1. Thorp JA, Helfgott AW, King EA, King AA, Minyard AN. Maternal death after second trimester genetic amniocentesis. Obstet Gynecol 2005;105:1213-5.

2. Lambl D. Ein seltener Fall von Hydramnios. Zentralblatt Gynaekologie 1881;5:329.

3. Nadler HL, Gerbie AB. Role of amniocentesis in intrauterine detection of genetic disorders. $N$ Engl J Med 1970;282:596-9.
4. Schmidt W, Gabelmann J, Müller U, Voigtlander T, Hager HD, Schroeder TM, et al. Genetic amniocentesis: techniqu$\mathrm{e}$ and results in 1,000 first trimester amniocentesis. Geburtshilfe Frauenheilkd 1980;40:761-8.

5. Mohr J. Foetal genetic diagnosis. Development of techniques for early sampling of foetal cells. Acta Pathologica Microbiologic 1968;73:73-7.

6. Kazy Z, Rozovsky I, Bakhaeve V. Chorion biopsy in early pregnancy; a method of early prenatal diagnosis for inherited disorders. Prenat Diagn 1982;2:39-45.

7. Young SR, Shipley CF, Wade RV, Edwards JG, Waters MB, Cantu ML, et al. Single-center comparison of result of 1000 prenatal diagnosis with chorionic villus sampling of diagnosis with 1000 diagnosis with amniocentesis. Am J Obstet Gynecol 1991; 165:255-63.

8. Spencer K, Souter V, Tul N, Snijders R, Nicolaides KH. A screening program for trisomy 21 at 10-14 weeks using fetal nuchal translucency, maternal serum free beta-human chorionic gonadotropin and pregnancy-associated plasma protein-A. Ultrasound Obstet Gynecol 1999;13:231-7.

9. Schmorl G. Pathologisch-anatomische Untersuchungen über Puerperal-Eklampsie. Leipzig: Verlag FCW Vogel; 1893.

10. Von Eggeling F, Michel S, Günther M, Schimmel B, Claussen U. Determination of the origin of single nucleated cells in maternal circulation by means of random PCR and a set of length polimorphisims. Hum Genet 1997;99:266-70.

11. Cunningham J, Yates Z, Hamlington J, Mason G, Mueller R, Miller D. Non-invasive RNA-based determination of fetal Rhesus D type: a prospective study based on 96 pregnancies. Br J Obstet Gynaecol 1999;106:1023-8.

12. Bianchi DW, Simpson JL, Jackson LG, Elias S. Fetal gender and aneuploidy detection using fetal cells in maternal blood: analysis of NIFTY I data. National Institute of Child Health and Development Fetal Cell Isolation Study. Prenat Diagn 2002;22:609-15.

13. Costa JM, Benachi A, Gautier E, Jouannic JM, Ernault P, Dumez Y. First trimester fetal sex determination in maternal serum using real-time PCR. Obstet Fertil 2002;30:953-7.

14. Chiu RW, Akolekar R, Zheng YW, Leung TY, Sun H, Chan $\mathrm{KC}$, et al. Non- invasive prenatal assessment of trisomy 21 by multiplexed maternal plasma DNA sequencing: large scale validity study. BMJ 2011;11:342:c7401.

15. Şener KT. Kliniğimizde 7 yıllık amniosentez sonuçları. Perinatoloji Dergisi 2006;14:170-5.

16. Api O, Özyapı AG, Cengizoğlu B, Ünal O, Turan MC. Yedi yıllık ikinci trimester genetik amniyosentez sonuçlarımız. Perinatoloji Dergisi 2009;17:1-7.

17. Yüce H, Çelik H, Gürateş B, Erol D, Hanay F, Elyas H. Karyotip analizi amaciyla genetik amniyosentez uygulanan 356 olgunun retrospektif analizi. Perinatoloji Dergisi 2006;14:73-6.

18. Reynolds $\mathrm{T}$. The triple test as a screening technique for Down syndrome: reliability and relevance. International Journal of Women's Health 2010;2:83-8.

19. ACOG Practice Bulletin No. 77. Screening for fetal chromosomal. Obstet Gynecol 2007;109:217-27. 
20. Ermiş H. 11.-14. gebelik haftası trizomi tarama testinin klinik rutine oturtulması. Istanbul Jinekoloji ve Obstetrik Dergisi 2000;4:52- 8.

21. Tabor A, Jerne D, Bock JE. Incidence of rhesus immunization after genetic amniocentesis. Br Med J 1986;293:533-6.

22. Şener T, Özalp S, Hassa H, Yalçin OT, Polay S. Maternal blood clot teraphy: a model for post amniocentesis amniorrhea. Am J Obstet Gynecol 1997;177:1535-6.
23. Andreasen E, Kristofferson K. Incidence of sponteneos abortion after amniocentesis: influence of placental localisation and past obstetric and gynecologic history. Am J Perinatol 1989;6:268-73.

24. Yıldırım G, Aslan H, Gül A, Güngördük K, Aktaş FN, Çakmak D ve ark. İkinci trimester genetik amniyosentez sonras1 gebelik sonuçları: 1070 olgunun değerlendirmesi. Perinatoloji Dergisi 2006;14:117-121. 